\title{
Alleghanian faulting in the southern Gaspé Peninsula of Quebec
}

\author{
P. Jutras, ${ }^{1}$ G. Prichonnet, ${ }^{2}$ and S. McCutcheon ${ }^{3}$ \\ 1. Department of Geology, Saint Mary's University, Halifax, NS B3H 3C3 <pierre.jutras@smu.ca> \\ 2. GEOTERAP, Département des Sciences de la Terre et de l'Atmosphère, Université du Québec à Montréal, \\ C.P. 8888, Succ. Centre-ville, Montréal, QC H3C 3P8 \\ 3. New Brunswick Department of Natural Resources, P.O. Box 50, Bathurst, NB E2A 3Z1
}

Date received:July 11,2003 I Date accepted:January 7,2004

\begin{abstract}
Transcurrent faults and associated compressional structures affecting post-Middle Devonian rocks are recognized for the first time in the southern Gaspé Peninsula (Quebec). This region was previously thought to have experienced only minor normal fault readjustments after the Middle Devonian Acadian Orogeny. Four SW-striking fault systems with post-Acadian sinistral motion that have been identified along the north shore of Chaleur Bay are described here. These faults are kinematically compatible with large NW-striking dextral faults in eastern Gaspé, and suggest that these structures reflect a widespread Alleghanian paleostress system that probably affected the entire Quebec Appalachians.

\section{RÉSUMÉ}

Des failles de décrochement et les structures compressives qui leur sont associées affectent des roches post-Dévonien moyen dans le sud de la Gaspésie (Québec) et sont reconnues pour la première fois. Cette région était auparavant considérée comme n'ayant connu que des réajustements mineurs de failles normales après l'orogenèse Acadienne (Dévonien moyen). Quatre systèmes de failles orientées SW-NE ont connus des déplacements senestres post-acadiens et sont analysés dans cet article. Ces failles sont compatibles avec de grands décrochements dextres orientés NW-SE dans l'est de la Gaspésie et suggèrent que ces structures sont associées à des paléostress alléghaniens ayant possiblement affecté les Appalaches québécoises dans leur totalité.
\end{abstract}

[Traduit par la rédaction]

\section{INTRODUCTION}

Following identification of post-Acadian (post-Middle Devonian) paleostress indicators in the Quebec Appalachians by Faure et al. (1996), significant Alleghanian deformation was recently reported in the eastern Gaspé Peninsula near the town of Percé (Jutras et al. 2003) (Fig. 1, inset). The present paper reveals that transcurrent and associated compressive structures also affected the narrow belt of Carboniferous rocks that is exposed on the northern shore of Chaleur Bay, in southern Gaspé (Fig. 1). The eastern Gaspé structures are dextral faults striking NW to NNW, but the southern Gaspé structures discussed herein are sinistral faults striking NE (Figs. 2 and 3).

This paper provides a structural analysis of faults affecting Carboniferous rocks in southern Gaspé, which contains the northwesternmost rock exposures of the composite Upper Devonian to Permian Maritimes Basin(Fig. 1; inset). The fault traces tend to form well defined scarps because of the juxtaposition of poorly-indurated post-Acadian rocks with more resistant pre- and syn-Acadian rocks. Hence, some geomorphic descriptions are included, as they help to delineate the faults.

\section{GEOLOGICAL SETTING}

Pre-Carboniferous rocks in southern Gaspé range in age from Neoproterozoic to Early Devonian (Brisebois et al. 1992). Upper Neoproterozoic to Cambrian metasedimentary and volcanic rocks of the Maquereau Group were first deformed by the Late Cambrian to Early Ordovician Gaspesian Orogeny (Ayrton 1967). Middle Ordovician sandstone and mudrock of the Mictaw Group were first deformed by the Middle Ordovician Taconian Orogeny, which for most authors includes the Late Cambrian to Early Ordovician Gaspesian deformation as an early phase (Rodgers 1967; St-Julien and Hubert 1975; de Broucker 1987). Upper Ordovician to Lower Devonian sedimentary rocks of the Honorat, Matapedia and Chaleurs groups, as well as volcanic rocks of the latter group, were first deformed by the Early to Middle Devonian Acadian Orogeny (Malo and Béland 1989; Malo et al. 1992, 1995; Malo and Kirkwood 1995; Bourque et al. 2000; Kirkwood et al. 1995) (Figs. 2 and 3).

The post-Acadian succession in southern Gaspé starts with the Frasnian Miguasha Group (Brideaux and Radforth 1970; 


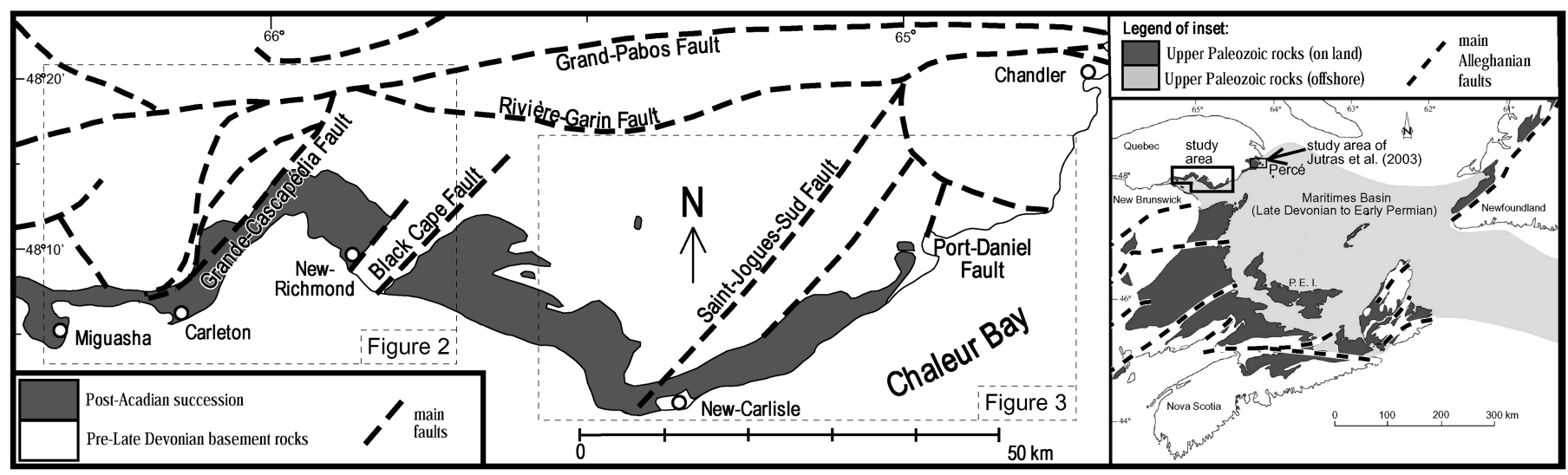

Fig. 1 Simplified geology of the southern Gaspé Peninsula (modified from Brisebois et al. 1992) showing only post-Acadian relationships, with map areas of figures 2 and 3 outlined. Inset is modified from Gibling et al. (1992).

Hesse and Sawh 1992; Prichonnet et al. 1996), which was gently deformed prior to deposition of the Late Devonian to Early Mississippian Saint-Jules Formation (Jutras and Prichonnet 2002) (Fig. 4). The latter occupies approximately the same stratigraphic position as the Fountain Lake Group of Nova Scotia and is also lithologically similar.

The overlying fanglomerates of the La Coulée Formation of eastern Gaspé (Jutras et al. 1999), which are stratigraphically constrained to the Viséan (Jutras et al. 2001), have not been recognized in southern Gaspé. However, the groundwater calcretization event that is contemporaneous with this formation affected the southern Gaspé area as well, above the Saint-Jules Formation and unconformably below the Viséan Bonaventure Formation (Jutras et al. 1999, 2001; Jutras and Prichonnet 2002)(Fig. 4). The calcrete locally digested a karstified regolith developed in the upper beds of the Saint-Jules Formation, suggesting that a significant hiatus separates the Saint-Jules and La Coulée formations (Jutras and Prichonnet 2002)(Fig. 4).

The youngest sedimentary rock unit in southern Gaspé is the early Namurian Pointe Sawyer Formation (Fig. 4), which has very limited exposure (Fig. 3) and which disconformably overlies the Bonaventure Formation. This unit was correlated with the early Namurian Mabou Group of Nova Scotia on the basis of spore-age and lithological similarities (Jutras et al. 2001) (Fig. 4).

The entire post-Acadian succession of eastern Gaspé, up to the Namurian Chemin-des-Pêcheurs Formation (Jutras et al. 2001), which is not exposed in southern Gaspé, was affected by compressive deformation and kilometric strike-slip displacements (Jutras et al. 2003). Four additional strike-slip fault corridors recognized in the post-Acadian succession of southern Gaspé are described below.

\section{THE GRANDE-CASCAPÉDIA FAULT SYSTEM}

Steeply dipping strata of the Bonaventure Formation along the Petit-Montréal and Mont-Saint-Joseph faults in the
Carleton area (Fig.2) have been attributed to a $\sim 600 \mathrm{~m}$ normal splay of that fault system (Bernard and St-Julien 1986), although no kinematic indicators were documented. Gosselin (1988) also postulated that the Bonaventure Formation was affected by a normal splay of the Grande-Cascapédia Fault (Fig. 2) on account of its anomalously steep dip adjacent to the associated fault scarp (Fig. 5).

Gosselin (1988) considered the converging Petit-Montréal, Mont-St-Joseph and Grande-Cascapédia faults (GrandeCascapédia fault system) as steeply dipping late Acadian reverse faults that were active subsequent to regional Acadian folding, but also reports evidence for sinistral and, to a lesser degree, dextral movement along subordinate structures of the deformation corridor. The possibility that the present disposition of the Mississippian strata could have been related to that reverse splay, rather than to a subsequent normal splay, has never been evaluated.

Near Carleton (Fig. 2), the measured dips of Mississippian beds increase from east to west in the proximity of the GrandeCascapédia fault system, until they become slightly overturned (Fig. 6a). The strikes of these beds rotate counter-clockwise along with the dip increase (Fig. 2a).

The subvertically tilted Mississippian beds that are exposed near the Grande-Cascapédia fault system at Carleton, which is not exposed at its contact with Mississippian rocks, are affected by brittle fault planes $(\mathrm{n}=5)$ striking NNE and plastered with sinistral slickensided calcite fibers (Figs. 6b and 2, stereonet 1; Table 1). One WNW-striking dextral fault plane with a similar fabric was also identified (Fig. 2, stereonet 1; Table 1). Moreover, two minor east-striking reverse fault planes plastered with calcite slickenfibers were identified in Mississippian rocks of the nearby Saint-Jules-de-Cascapédia quarry (Fig. 2, stereonet 2; Table 1).

The described structures are incompatible with the normal fault hypothesis formulated by previous authors (Bernard and St-Julien 1986; Gosselin 1988). However, they are compatible with sinistral movement along the Grande-Cascapédia fault system, with the sinistral and dextral shears (Fig. 2, stereonet 1) being interpreted as, respectively, $R$ and R' synthetic Riedel 


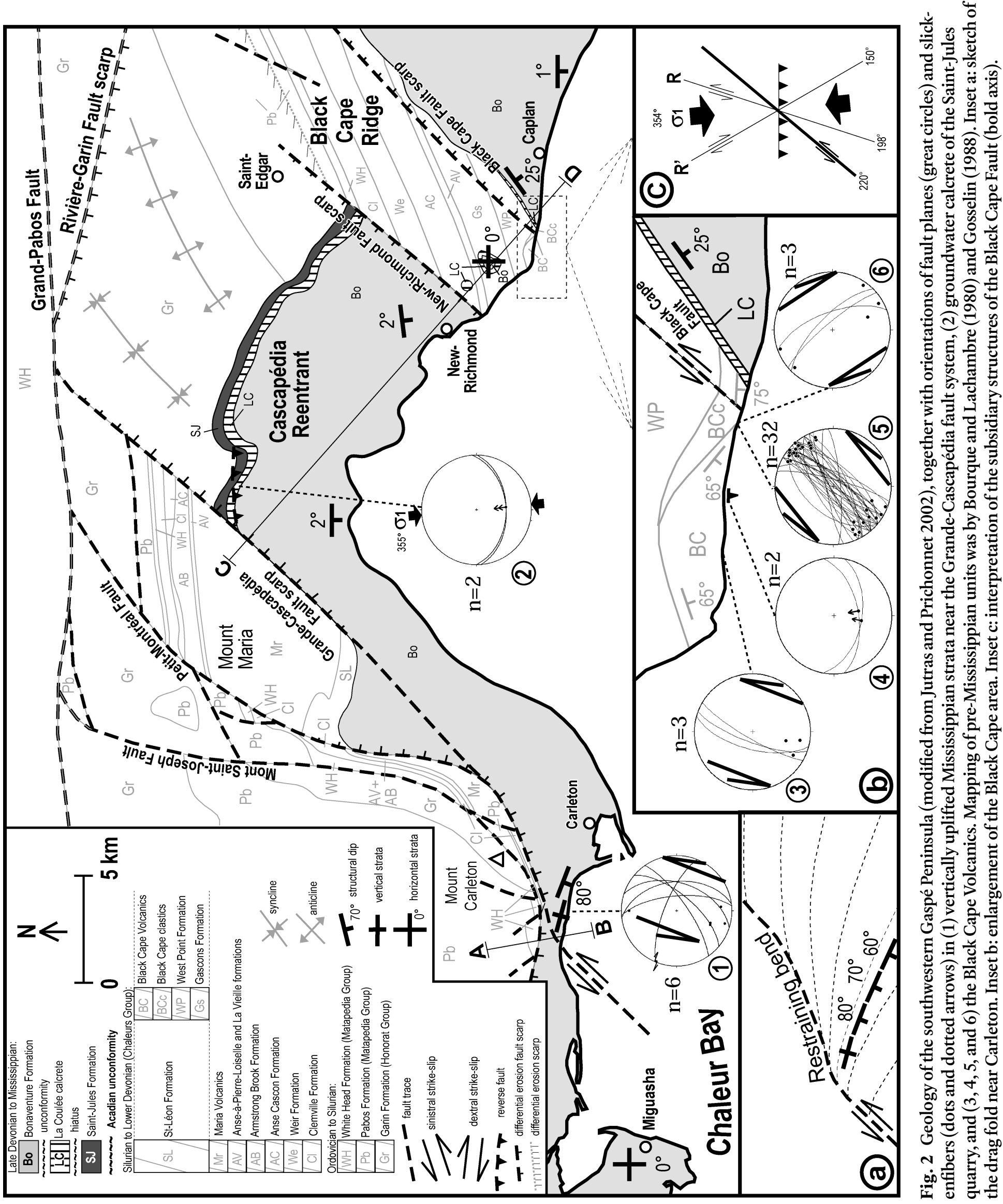



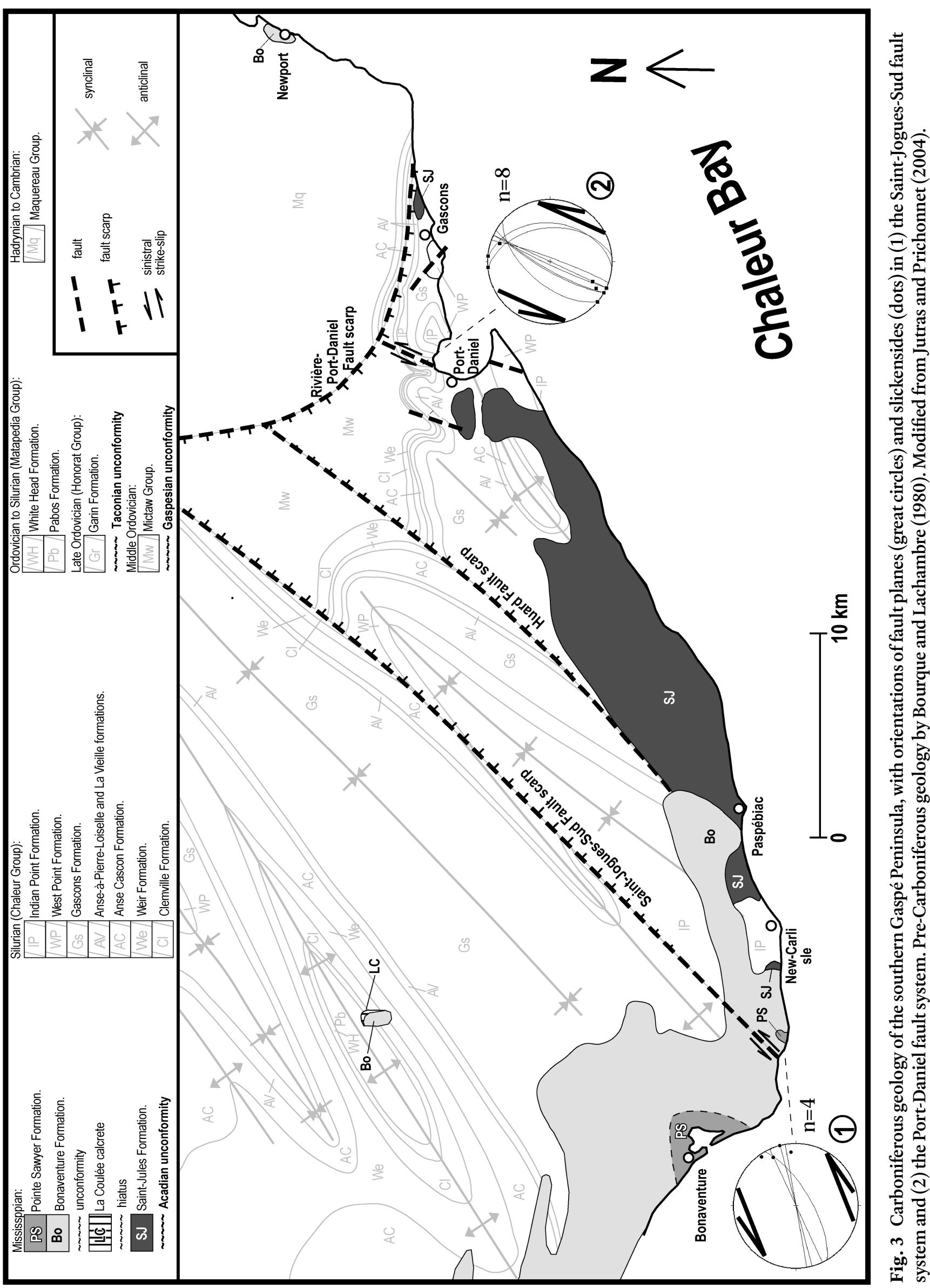
Table 1. Structural data used in this study.

\begin{tabular}{|c|c|c|c|c|c|}
\hline \multirow{2}{*}{$\begin{array}{c}\text { Stereonet } \\
\text { locality }\end{array}$} & \multicolumn{2}{|c|}{ Fault plane } & \multicolumn{2}{|c|}{ Slickenfibre } & \multirow{2}{*}{$\begin{array}{c}\text { Sense of } \\
\text { displacement }\end{array}$} \\
\hline & strike $\left(^{\circ}\right)$ & $\operatorname{dip}\left({ }^{\circ}\right)$ & plunge $\left(^{\circ}\right)$ & trend $\left({ }^{\circ}\right)$ & \\
\hline \multicolumn{6}{|c|}{ Southwest Gaspé(Fig. 2) } \\
\hline 1 & 353 & 46 & 14 & 360 & sinistral \\
\hline 1 & 18 & 48 & 10 & 195 & sinistral \\
\hline 1 & 40 & 66 & 34 & 203 & sinistral \\
\hline 1 & 55 & 75 & 35 & 200 & sinistral \\
\hline 1 & 355 & 68 & 20 & 175 & sinistral \\
\hline 1 & 292 & 72 & 0 & 292 & dextral \\
\hline 2 & 85 & 45 & 45 & 175 & reverse \\
\hline 2 & 90 & 45 & 45 & 175 & reverse \\
\hline 3 & 200 & 75 & 18 & 190 & sinistral \\
\hline 3 & 220 & 80 & 20 & 210 & sinistral \\
\hline 3 & 195 & 65 & 39 & 195 & sinistral \\
\hline 4 & 80 & 55 & 55 & 170 & reverse \\
\hline 4 & 100 & 50 & 50 & 190 & reverse \\
\hline 5 & 40 & 89 & 30 & 215 & sinistral \\
\hline 5 & 211 & 89 & 30 & 200 & sinistral \\
\hline 5 & 259 & 81 & 15 & 70 & sinistral \\
\hline 5 & 221 & 75 & 20 & 220 & sinistral \\
\hline 5 & 58 & 80 & 20 & 60 & sinistral \\
\hline 5 & 242 & 65 & 30 & 240 & sinistral \\
\hline 5 & 85 & 80 & 7 & 85 & sinistral \\
\hline 5 & 245 & 86 & 10 & 245 & sinistral \\
\hline 5 & 51 & 85 & 15 & 50 & sinistral \\
\hline 5 & 52 & 65 & 10 & 50 & sinistral \\
\hline 5 & 241 & 84 & 60 & 15 & sinistral \\
\hline 5 & 221 & 50 & 40 & 15 & sinistral \\
\hline 5 & 35 & 81 & 8 & 35 & sinistral \\
\hline 5 & 31 & 79 & 5 & 210 & sinistral \\
\hline 5 & 251 & 80 & 10 & 70 & sinistral \\
\hline 5 & 41 & 77 & 10 & 40 & sinistral \\
\hline 5 & 60 & 80 & 20 & 60 & sinistral \\
\hline 5 & 21 & 86 & 20 & 40 & sinistral \\
\hline 5 & 30 & 78 & 10 & 50 & sinistral \\
\hline 5 & 225 & 82 & 10 & 45 & sinistral \\
\hline 5 & 31 & 81 & 15 & 30 & sinistral \\
\hline 5 & 39 & 60 & 18 & 40 & sinistral \\
\hline 5 & 21 & 69 & 4 & 200 & sinistral \\
\hline 5 & 210 & 83 & 12 & 30 & sinistral \\
\hline 5 & 219 & 72 & 5 & 40 & sinistral \\
\hline 5 & 29 & 76 & 2 & 39 & sinistral \\
\hline 5 & 52 & 84 & 15 & 52 & sinistral \\
\hline 5 & 49 & 88 & 8 & 50 & sinistral \\
\hline 5 & 41 & 78 & 15 & 41 & sinistral \\
\hline 5 & 39 & 87 & 12 & 38 & sinistral \\
\hline 5 & 51 & 72 & 1 & 52 & sinistral \\
\hline 5 & 35 & 73 & 11 & 215 & sinistral \\
\hline 6 & 160 & 80 & 35 & 160 & dextral \\
\hline \multirow[t]{2}{*}{6} & 317 & 70 & 8 & 315 & dextral \\
\hline & & & 5 & 135 & dextral \\
\hline \multirow[t]{2}{*}{6} & 340 & 65 & 5 & 340 & dextral \\
\hline & & & 7 & 160 & dextral \\
\hline \multicolumn{6}{|c|}{ Southern Gaspé (Fig. 3) } \\
\hline 1 & 75 & 90 & 0 & 75 & sinistral \\
\hline 1 & 60 & 70 & & & \\
\hline \multirow[t]{2}{*}{1} & 260 & 90 & 15 & 85 & sinistral \\
\hline & & & 5 & 55 & sinistral \\
\hline 1 & 245 & 90 & 15 & 65 & sinistral \\
\hline 2 & 205 & 86 & 0 & 205 & sinistral \\
\hline 2 & 220 & 60 & 0 & 220 & sinistral \\
\hline 2 & 205 & 90 & 25 & 205 & sinistral \\
\hline 2 & 210 & 78 & 15 & 210 & sinistral \\
\hline 2 & 20 & 85 & 15 & 20 & sinistral \\
\hline 2 & 210 & 80 & 0 & 210 & sinistral \\
\hline 2 & 5 & 38 & 0 & 5 & sinistral \\
\hline 2 & 355 & 45 & 0 & 355 & sinistral \\
\hline
\end{tabular}

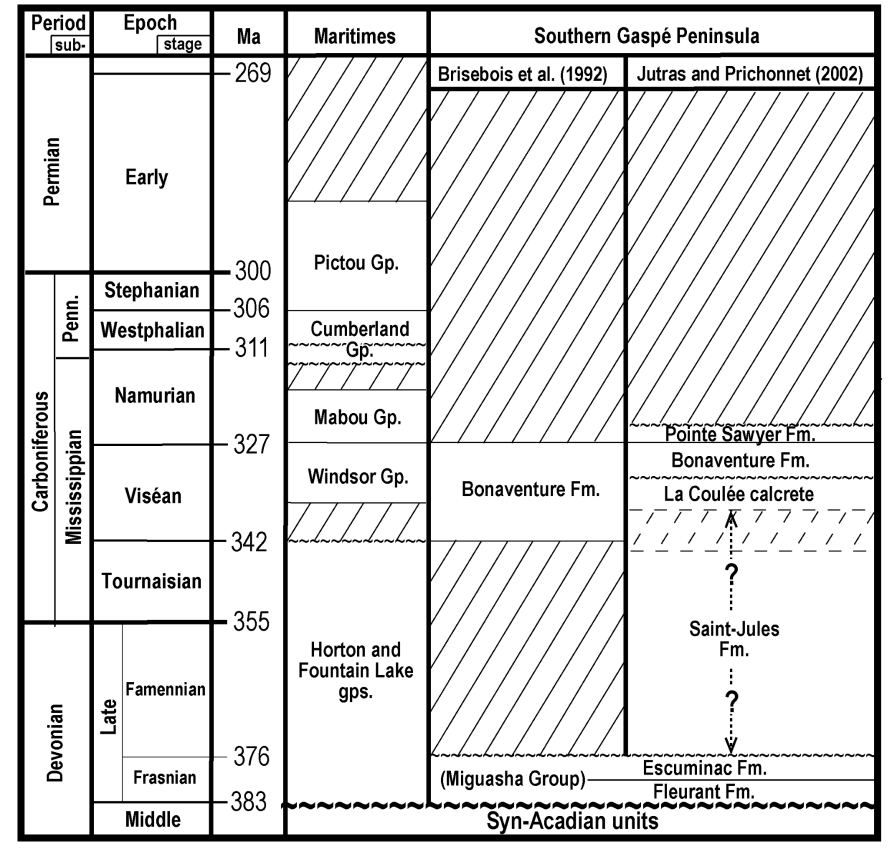

Fig. 4 Post-Acadian stratigraphic record in the Maritimes and in the Gaspé Peninsula. Time-scale after Okulitch (1999). Wavy lines represent unconformities and diagonal rulings represent major hiatuses. The stratigraphy of the Maritimes Basin is modified from Bell (1944), Mamet (1970), Howie and Barss (1975), Utting (1987), Utting et al. (1989), Ryan et al. (1991), Martel et al. (1993) and Calder (1998).

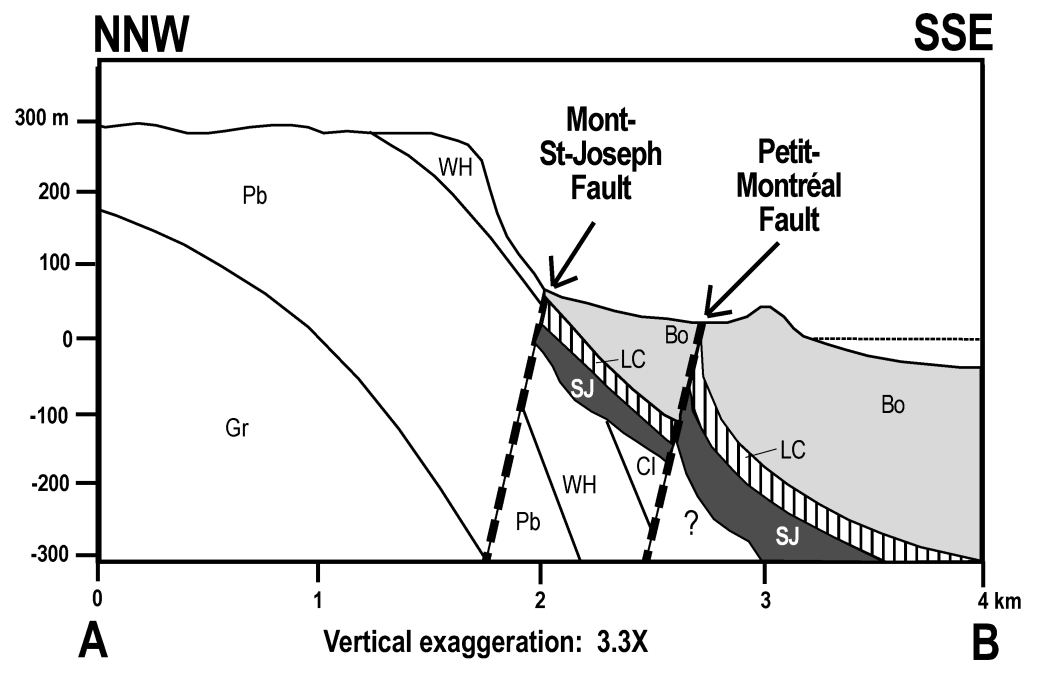

Fig. 5 Cross-section A-B (legend and transect shown on Fig. 2), showing the attitude of Carboniferous beds at the contact with the Petit-Montréal and Mont-St-Joseph faults of the Grande-Cascapédia fault system near Carleton. 

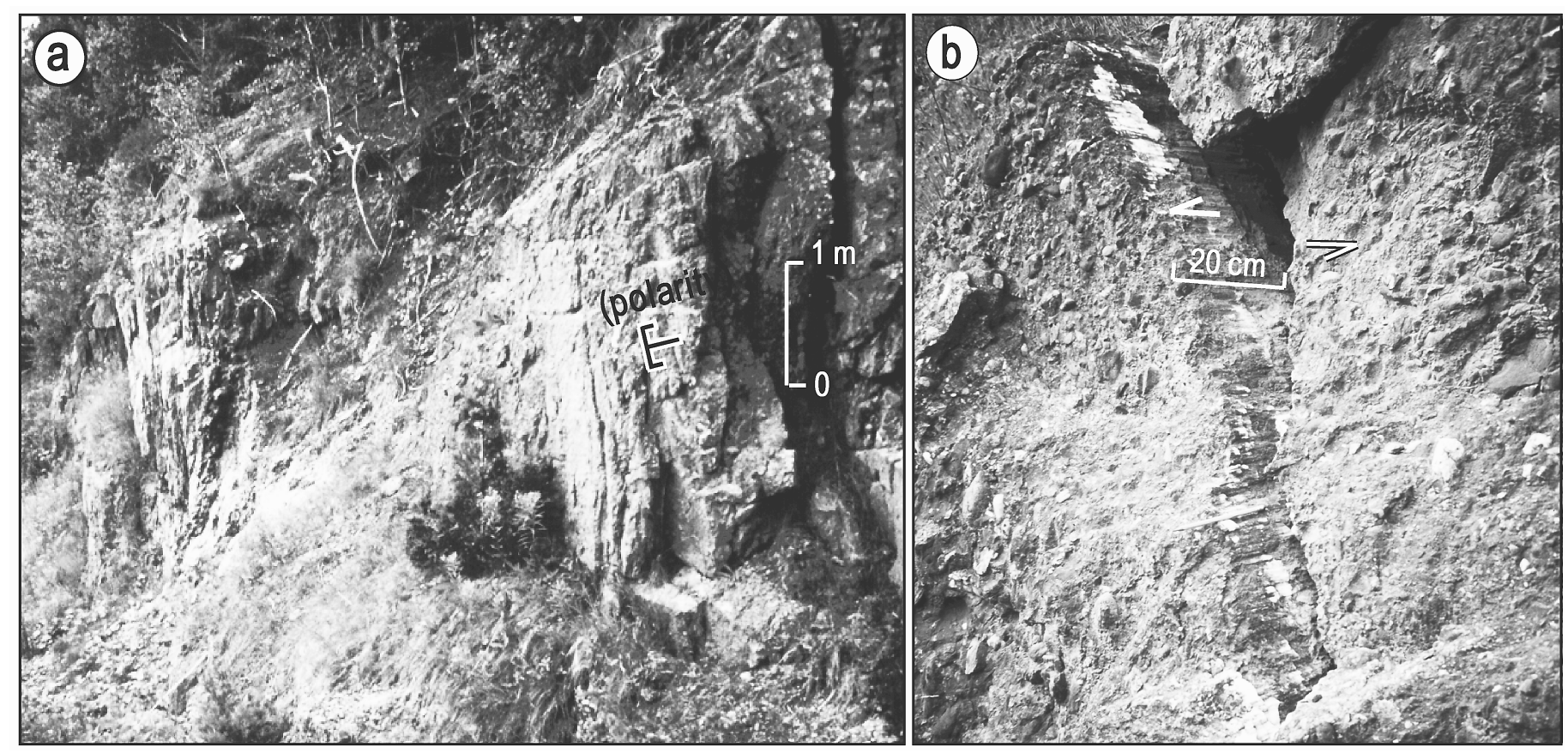

Fig. 6 (a) Vertical to slightly overturned strata of the Bonaventure Formation in the vicinity of the Grande-Cascapédia fault system. View is to the northwest. (b) Small sinistral fault delineated by white calcite slickenfibers and offsetting the tilted-on-edge strata. View is to the northwest.

structures on account of their angle with each other and with the main fault trace. The $175^{\circ}$ trend of slickensided fibers on the reverse faults is interpreted as corresponding closely to that of the main principal stress $\left(\sigma_{1}\right), \sim 30^{\circ}$ clockwise from the main fault trace and compatible with the approximately NNW-SSE $\sigma_{1}$ suggested by the conjugate $\mathrm{R}$ and R' structures (Wilcox et al. 1973). As for the overturned strata near Carleton, they are interpreted as the result of counter-clockwise rotation of a strike-slip drag fold along a restraining bend on the SE block (Fig. 2a), suggesting sinistral movement as well (Biddle and Christie-Blick 1985).

\section{THE BLACK CAPE AND NEW-RICHMOND FAULTS}

Jutras and Prichonnet (2002) identified and named the NewRichmond and Black Cape faults, which limit the Black Cape Ridge on each side and which locally affect the Mississippian succession (Figs. 2 and 7). No kinematic markers were found in the unexposed New-Richmond Fault trace, except for an apparent vertical displacement of $50 \mathrm{~m}$ (minimum) to $920 \mathrm{~m}$ (maximum)(Jutras and Prichonnet 2002).

The Black Cape Fault affected a Late Silurian to Early Devonian clastic unit that is unconformably overlain by the Viséan La Coulée calcrete and Bonaventure Formation (Figs. 2 and 7). This clastic unit below the unconformity was tentatively correlated with the New Mills Formation by Bourque et al. (2000). However, because it contains abundant limestone reef clasts from the Pridolian (uppermost Late Silurian) West Point Formation (Bourque and Lachambre 1980), correlation with the New Mills is not supported by the Ludlow (lowermost Late
Silurian) zircon U-Pb dating ( $423 \pm 3 \mathrm{Ma}$ ) from the Benjamin Volcanics (Walker and McCutcheon 1994), which overlie the New Mills Formation in its type section (Greiner 1967). The red beds that were assigned to the New Mills Formation at Black Cape (Bourque et al. 2000) are possibly also younger than similar red beds of the Harrison Member of the West Point Formation farther west, which are separated from the Black Cape Volcanics by the Late Silurian Indian Point Formation(D. Brisebois, personal communication, 2003). Instead of referring to these red beds as the New Mills Formation, we propose to informally refer to them as the Black Cape clastics until they are more solidly incorporated into the regional stratigraphic context.

No exposures of Mississippian rocks were found directly on the New-Richmond and Black Cape fault traces. However, as shown on Figs. 2 and 7, they form scarps that truncate an erosional surface developed within rocks that were deformed by the Acadian Orogeny and therefore post date the latter event. Moreover, the Mississippian succession dips $25^{\circ}$ down from the Black Cape Fault on the SE block, but is sub-horizontal on the NW block, suggesting that it has been affected by movement on that fault. Hence, because the Mississippian succession of the Gaspé Peninsula is deformed only along faults and is otherwise flat-lying, it is postulated that the brittle deformation features observed in pre-Carboniferous basement rocks and described below are related to post-Viséan fault activity, although this interpretation is not fully demonstrated by available exposure. This interpretation is supported by the similarity and compatibility of these brittle structures with those affecting the Mississippian succession in the Carleton and Saint-Jules areas.

No kinematic indicators were identified directly on the SW- 


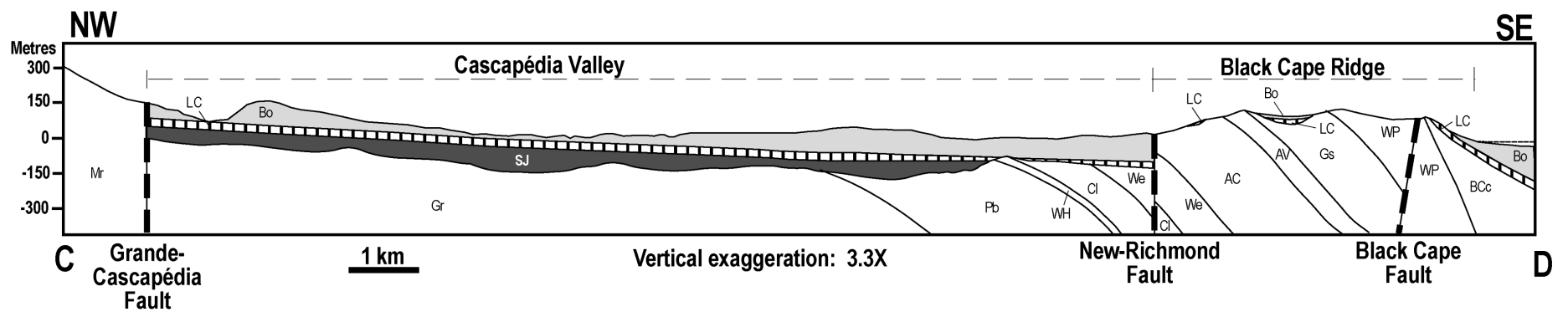

Fig. 7 Cross-section C-D (legend and transect shown on Fig. 2), showing the attitude of Carboniferous beds at the contact with the Black Cape Fault. Thickness of the La Coulée calcrete is exaggerated for better visibility. Modified from Jutras and Prichonnet (2002).

striking Black Cape Fault trace, which is characterized by a 30 $\mathrm{cm}$ thick cataclastic corridor. Less than $1 \mathrm{~km}$ west of the Black Cape Fault along the shoreline, a thin succession of red clastic rocks, which Bourque and Lachambre (1980) informally refer to as the Lazy Cove sedimentary unit, is intercalated between two lava flows of the Early Devonian Black Cape Volcanics. This clastic unit is almost entirely pulverised within a cataclastic corridor that contains no reliable kinematic indicators. However, at the contact between this deformed sedimentary unit and the adjacent lava flow, well developed NNE-striking brittle sinistral fault planes plastered with calcite slickenfibers can be observed (Fig. 2b, stereonet 3; Table 1).

Approximately $750 \mathrm{~m}$ west of the Black Cape Fault, a brittle reverse fault, striking E-W, occurs within the Black Cape Volcanics (Fig. 2b). It is characterized by a $5 \mathrm{~m}$ thick cataclastic corridor developed in volcaniclastic rocks. Two subordinate reverse fault planes developed in basalt on the footwall of the main fault are plastered with calcite slickenfibers that are steeply plunging toward the south (Fig. 2b, stereonet 4; Table 1).

Within 50 to $150 \mathrm{~m}$ west of the Black Cape Fault, a dense network of brittle sinistral fault planes striking roughly NE and plastered with calcite slickenfibers (Fig. 2b, stereonet 5; Table 1) is truncated by a less dense network of dextral fault planes with similar fabrics striking NW (Fig. 2b, stereonet 6; Table 1). It is noteworthy that these Riedel fault planes (Fig. 2b, stereonets 3-6) are restricted to the Black Cape Volcanics and do not extend into the underlying 'Black Cape clastics' (Fig. 8). The fault planes abruptly stop at the contact between the two steeply dipping units. This observation indicates that movement on each of these secondary fault planes was centimetric in scale and only generated clearly defined brittle offsets in the volcanic rocks, whereas the underlying Black Cape clastics only responded to the stress by bending slightly. It also underlines the poor capacity of clastic rocks to develop Riedel structures, even when they are as well indurated as the 'Black Cape clastics', which experienced the Acadian Orogeny.

Data on stereonets 3-6 (Fig. 2b) are compatible with sinistral motion on the Black Cape Fault (strike $040^{\circ}$ ), with the sinistral planes of stereonet 3 being interpreted as R structures, the dextral planes of stereonet 6 as R' structures, and the sinistral planes of stereonet 5 as a poorly constrained combination of $\mathrm{P}$ and $\mathrm{R}$ structures, the average orientation of which $\left(044^{\circ}\right)$ closely reflects that of the main fault trace $\left(\sim 040^{\circ}\right)$ (Fig. 2c).
Also compatible with sinistral motion on that fault is the geometry of drag folding along the fault (Fig. 8). No reliable stratigraphic markers were identified to quantify the displacement, but kilometric displacement is considered unlikely due to the lack of major stratigraphic breaks along the fault. A main principal stress with a trend of $174^{\circ}-354^{\circ}$ is obtained halfway between the average R structures of stereonet 3 and the average R' structures of stereonet 6, which is compatible with the strike and slickenfiber orientation of the two reverse faults of stereonet 4 (Fig. 2b, c).

\section{THE SAINT-JOGUES-SUD FAULT}

Jutras and Schroeder (1999) named the Saint-Jogues-Sud Fault (Fig. 3) and attributed it to post-Acadian tectonic activity because it sharply truncates a post-Acadian erosional surface. As is the case for the Grande-Cascapédia and Black Cape faults, the NW block is uplifted with regards to the SE block. On air photos, the fault forms a well defined linear feature that transects the Bonaventure Formation west of New-Carlisle (Fig. 3), but the fault zone is not exposed within this unit. However,

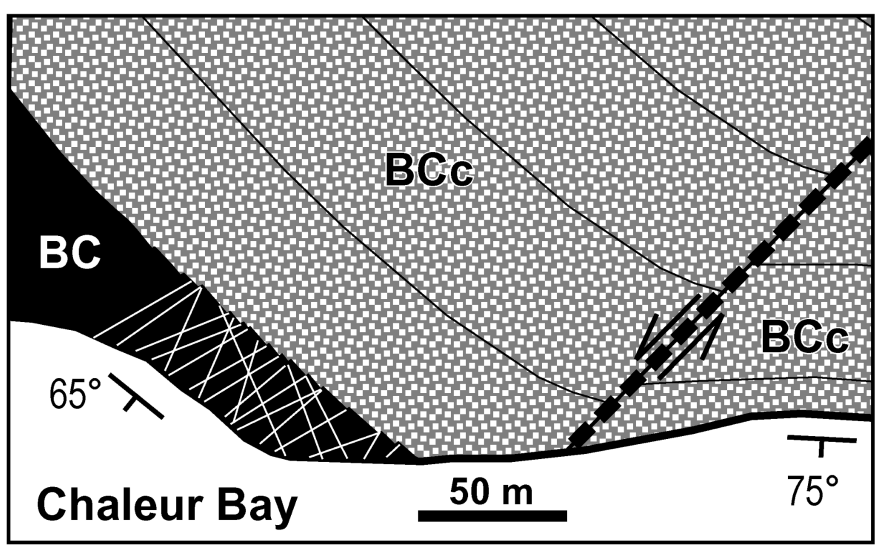

Fig. 8 Schematic representation of the field observations at Black Cape, where a tight network of Riedel structures (white lines) abruptly stops at the sub-vertical contact between the Black Cape Volcanics (BC) and older strata informally assigned to the Black Cape clastics $(\mathrm{BCc})$ in the vicinity of the Black Cape Fault (dashed line). 
four ENE-striking brittle fault planes, two of which have surfaces that exhibit sinistral slickensides, are postulated to represent $P$ structures associated with a sinistral splay of this fault because of their acute angle $\left(\sim 25^{\circ}\right)$ with it (Fig. 3 , stereonet 1 ; Table 1). The lack of major facies differences in Bonaventure Formation strata on either side of the trace of the Saint-JoguesSud Fault suggests minimal displacement, although this is difficult to establish within horizontal clastic beds that typically show significant lateral variability.

\section{THE PORT-DANIEL FAULT}

The Port Daniel area (Fig. 3) is characterized by a rugged Late Devonian paleosurface dominated by the Clemville Hogbacks, which are sculpted in Silurian limestone of the La Vieille and West Point formations (Bourque and Lachambre 1980; Bail 1983; Jutras 1995; Peulvast et al. 1996; Jutras and Schroeder 1999). After being buried by red clastic sediments of the Saint-Jules Formation during the Late Devonian or the early Mississippian, these hogbacks developed karstic features during early stages of their subsequent exhumation, which occurred after deposition of the Bonaventure Formation (Jutras and Schroeder 1999). Material derived from the Carboniferous cover synchronously filled the karsts.

A limestone quarry in one of the hogbacks, on the northeastern side of Port-Daniel, exposes a dense network of NNEstriking brittle fault planes with minor $\mathrm{N}$-striking fault planes affecting both the limestone of the La Vieille Formation and the red clastic rocks within the karsts (Fig. 3, stereonet 2; Table 1). Slickensided calcite fibers plastered on several fault planes indicate sinistral movement. No major structures were recognized in the local Silurian succession, and therefore the SSE-striking fault planes may have accommodated most of the stress, whereas $\mathrm{N}$-striking fault planes could correspond to $\mathrm{R}$ structures developed around them.

Karst is preferentially developed along the fault planes, which also affect the karst-fill. Hence, it is concluded that fault activity, karst formation, and karst infill were contemporaneous in this sector. If correlation of the karst-fill with the Bonaventure Formation detritus is correct (Peulvast et al. 1996; Jutras and Schroeder 1999), the deformation was postViséan.

\section{LATE TENSILE FRACTURES}

Vertical tensile fractures filled with calcite, ranging from a few millimetres to more than $10 \mathrm{~cm}$ in width, are common throughout the post-Acadian succession in the Gaspé Peninsula. The veins are either laminated or massive. Orientation of the tensile fracture-cast veins is extremely regular, from one end of the peninsula to the other, where they strike $040^{\circ}-220^{\circ}\left( \pm 5^{\circ}\right)$. They are not concentrated in the above-mentioned fault zones, which suggests that they are not coeval with them. The tensile veins are parallel to large Mesozoic mafic dykes cutting through the New Brunswick Platform, less than $100 \mathrm{~km}$ to the south (New Brunswick Department of Natural Resources and Energy 2000). Both features are probably related to extensional stress associated with the initial opening of the Fundy Rift and Atlantic Ocean in the Triassic to Jurassic.

\section{DISCUSSION AND CONCLUSIONS}

The paucity of paleostress indicators in Mississippian rocks of the Gaspé Peninsula led several authors to conclude that these rocks were not affected by late brittle strike-slip deformation affecting older rocks (Alcock 1935; St-Julien and Hubert 1975; Bernard and St-Julien 1986; Kirkwood 1989; Bourque et al. 1993), which Malo and Kirkwood (1995) and Kirkwood et al. (1995) associated with the "Acadian Phase III". However, this scarcity can be explained by the poorly consolidated, coarse-grained nature of the rocks involved. The Black Cape exposures, where abundant slickensided fault planes abruptly end at the contact between Early Devonian basalt and underlying clastic rocks (Fig. 8), underline the fact that coarse clastic rocks are poor recorders of paleostress indicators compared to more massive, fine-grained and competent rocks such as basalt. A similar contrast between the respective abundances in Riedel structures in massive fine-grained rocks (carbonate in this case) and coarse clastic rocks was also noted in the eastern Gaspé area (Jutras et al. 2003).

The SW-striking sinistral faults of southwestern Gaspé (Fig. 2) are possibly coeval with the NW-striking dextral strikeslip faults that were identified by Jutras et al. (2003) in eastern Gaspé, as both sets of faults are compatible with a NNW- to $\mathrm{N}$-trending main principal stress $\left(\sigma_{1}\right)$ (Fig. 2c). Contrary to the eastern Gaspé area, where only Alleghanian Riedel structures related to a late $\mathrm{NE}$-trending $\sigma_{1}$ are well preserved, Alleghanian Riedel structures related to an early NNW- to N-trending $\sigma_{1}$ are well represented in southern Gaspé and support the more indirect evidence for this paleostress orientation in eastern Gaspé, which is thought to have generated the most important block displacements in that area (Jutras et al. 2003).

Whereas evidence for the reactivation of inherited faults is present in eastern Gaspé (Jutras et al. 1999, 2003), such evidence is lacking in southern Gaspé. None of the brittle structures described in this paper intermingle with older ductile-brittle structures, apart from the Acadian folding. Only the Grande-Cascapédia fault system shows significant displacement of pre-Carboniferous units, but this fault system is also the only one in southern Gaspé that overturned Carboniferous rocks and seemingly generated kilometric displacement, as movement of such a scale is necessary to form the large drag fold that developed along its trace (Fig. 2a).

The lack of large post-Acadian SW-striking sinistral strikeslip faults in eastern Gaspé may be related to the former presence of NW-striking faults, which easily accommodated a 
roughly N-S main paleostress by experiencing dextral motion. On the other hand, sinistral strike-slip occurred on SW-striking faults in southern Gaspé as a response to the same stress, possibly reflecting the SW-striking Acadian tectonic grain in that area (Figs. 2 and 3), along which rocks were mechanically weaker.

Although we cannot identify evidence for a clockwise rotation of paleostress from the NNW to the NE in southern Gaspé, as was proposed for eastern Gaspé (Jutras et al. 2003), it should be pointed out that Faure et al. (1996) recorded evidence for such rotation in Carboniferous rocks of the Carleton area, but did not conclude that any significant block displacement was involved. Faure et al. (1996) also recorded evidence for this clockwise rotation of paleostress in Late Devonian plutons of southern Quebec, more than $500 \mathrm{~km}$ to the southwest. Hence, post-Acadian faults in the Gaspé Peninsula may be local expressions of a regional stress regime that may have affected much of the Canadian Appalachian orogen.

Jutras et al. (2003) proposed that both the formation and deformation of the Maritimes Basin occurred in response to plate readjustments related to the closure of the Theic (Rheic for some authors) Ocean during the Carboniferous. Transcurrent Carboniferous structures similar to those presented in this paper have been reported in several areas of the nearby Maritime Provinces (Fralick and Schenk 1981; Bradley 1982; Keppie 1982; Ruitenberg and McCutcheon 1982; Nance and Warner 1986; Gibling et al. 1987, 2002; McCutcheon and Robinson 1987; Nance 1987; Yeo and Ruixiang 1987; Reed et al. 1993; Murphy et al. 1995; Pascucci et al. 2000) and are thought to be distal expressions of the Alleghanian Orogeny, which was most penetrative in the southeastern United States (Hatcher 1989).

In conclusion, results presented here indicate that the Alleghanian structures of eastern Gaspé are part of a set of structures that affected a large area, although their magnitude does not compare with that of older Acadian or Taconian structures. From this observation, it is suggested that Alleghanian block displacements also affected the southwestern sectors of the Québec Appalachians, which are devoid of Carboniferous rocks, but which are closer to areas of peak Alleghanian metamorphism in the southeastern United States.

\section{ACKNOWLEDGMENTS}

We wish to thank S. Faure, M. Bardoux, N. Goulet, J. Waldron, D. Roy, P. Cousineau, M. Gibling and V. Owen for constructive discussions during this project, which was supported by a doctoral fellowship from the Natural Sciences and Engineering Council of Canada (NSERC) to P. Jutras. We also thank B. Murphy and D. Kirkwood for constructive reviews that helped improve this paper.

\section{REFERENCES}

Alcock, F.J. 1935. Geology of the Chaleur Bay region. Geological Survey of Canada, Memoir 183, $146 \mathrm{p}$.

Ayrton, W.G. 1967. Région de Chandler - Port-Daniel. Ministère des Richesses Naturelles du Québec, RG 120, $197 \mathrm{p}$.

BAIL,P.1983. Problèmes géomorphologiques del'englacement et de la transgression marine pléistocènes en Gaspésie sudorientale. Unpublished Ph.D. thesis, McGill University, $356 \mathrm{p}$.

BELL, W.A. 1944. Carboniferous rocks and fossil floras of Northern Nova Scotia. Geological Survey of Canada Memoir 238, 276p.

Bernard, D., \& ST-Julien, P. 1986. Analyse structurale du Siluro-Dévonien du centre de la Gaspésie et du Carbonifère du sud et de l'est de la Gaspésie. Ministère de l'Énergie et des Ressources de la Province de Québec, MB 86-36, 132 p.

Biddle, K.T., \& Christie-Blick, N. 1985. Glossary - Strikeslip deformation, basin formation and sedimentation. In Strike-slip deformation, basin formation and sedimentation. Edited by K.T. Biddle and N. Christie-Blick. SEPM Special Publication 37, pp. 375-386.

Bourque, P. A., \& LACHAMBre, G. 1980. Stratigraphie du Silurien et du Dévonien basal du sud de la Gaspésie. Ministère de l'Énergie et des Ressources, Québec, ES-30, 123 p.

Bourque, P.A., Gosselin, C., Kirkwood, D., Malo, M., \& St.-Julien, P. 1993. Le Silurien du segment appalachien Gaspésie-Matapédia-Témiscouata: stratigraphie, géologie structurale et paléogéographie. Ministère de l'Énergie et des Ressources, Québec, MB 93-25, 115 p.

Bourque, P.-A., Malo, M., \& Kirkwood, D. 2000. Paleogeography and tectono-sedimentary history at the margin of Laurentia during Silurian to earliest Devonian time: The Gaspé Belt, Québec. Geological Society of America Bulletin, 112, pp. 4-20.

BRAdLEY, D.C. 1982. Subsidence of Late Paleozoic basins in the northern Appalachians. Tectonics, 1, pp. 107-123.

Brideaux, W.W., \& Radforth, N.W. 1970. Upper Devonian miospores from the Escuminac Formation, eastern Québec, Canada. Canadian Journal of Earth Sciences, 7, pp. 29-45.

Brisebois, D., Lachambre, G., \& Piché, G. 1992. Carte géologique, pp. Péninsule de la Gaspésie. Ministère de l’Énergie et des Ressources, Québec, DV 91-21, scale 1: 250000.

Calder, J.H. 1998. The Carboniferous evolution of Nova Scotia. In Lyell: the Past is the Key to the Present. Edited by D.J. Blundell and A.C. Scott. Geological Society of London, Special Publication 143, pp. 261-302.

DE BRouCKER, G. 1987. Stratigraphie, pétrographie et structure de la boutonnière de Maquereau-Mictaw. Ministère de l'Énergie et des Ressources, Québec, MM 86-03, 170 p.

Faure, S., Tremblay, A., \& Angelier, J. 1996. Alleghanian paleostress reconstruction in the northern Appalachians: 
Intraplate deformation between Laurentia and Gondwana. Geological Society of America Bulletin, 108, pp. 14671480.

Fralick, P.W., \& Schenk, P.E. 1981. Molasse deposition and basin evolution in a wrench tectonic setting: the Late Paleozoic, Eastern Cumberland Basin, Maritime Canada. In Sedimentation and Tectonics in Alluvial Basins. Edited by A.D. Miall. Geological Association of Canada Special Paper 23, pp. 77-97.

Gibling, M.R., Boehner, R.C., \& Rust, B.R. 1987. The Sydney Basin of Atlantic Canada: an Upper Paleozoic strikeslip basin in a collisional setting. In Sedimentary basins and basin-forming mechanisms. Edited by $\mathrm{C}$. Beaumont and A.J. Tankard. Canadian Society of Petroleum Geologists Memoir 12, pp. 269-285.

Gibling, M.R., Calder, J.H., Ryan, R., Van De Poll, H.W., \& Yeo, G.M. 1992. Late Carboniferous and Early Permian drainage patterns in Atlantic Canada. Canadian Journal of Earth Sciences, 29, pp. 338-352.

Gibling, M.R., Langenberg, W., Kalkreuth, W.D., WalDron, J.W.F., Courtney, R., Paul, J., \& Grist, A.M. 2002. Deformation of Upper Carboniferous coal measures in the Sydney Basin: Evidence for late Alleghanian tectonism in Atlantic Canada. Canadian Journal of Earth Sciences, 39, pp. 79-93.

Gosselin, C. 1988. Géologie de la région de Maria (Gaspésie). Ministère de l'Énergie et des Ressources, Québec, ET 87-01, 28p.

GreINER, H.R. 1967. Silurian-Devonian relationships of the Charlo map area, New Brunswick. In International Symposium on the Devonian System, Calgary, Alberta 1967. Edited by D.H. Oswald. Alberta Society of Petroleum Geologists, 2,pp. 973-979.

Hatcher, R.D., JR. 1989. Tectonic synthesis of the U.S. Appalachians. In The Appalachian-Ouachita orogen in the United States. Edited by R.D. Hatcher Jr., W.A. Thomas and G.W. Viele. Geological Society of America; Geology of North America, Volume F-2, pp. 511-535.

Hesse, R., \& Sawh, H. 1992. Geology and sedimentation of the Upper Devonian Escuminac Formation, Quebec, and evaluation of its paleoenvironment: lacustrine versus estuarine turbidite succession. Atlantic Geology, 28, pp. 347-363.

HowIE, R.D., \& Barss, M.S. 1975. Upper Paleozoic rocks of the Atlantic provinces, Gulf of St.-Lawrence and adjacent continental shelf. Geological Survey of Canada, Paper 7430, 2, pp. 35-50.

Jutras, P. 1995. Synthèse géomorphologique de la Gaspésie. Unpublished M. Sc. thesis, Université du Québec à Montréal, $109 \mathrm{p}$.

Jutras, P., \& Prichonnet, G. 2002, Stratigraphy, depositional setting and diagenetic history of the Saint-Jules Formation (Upper Devonian or Mississippian), a newly identified post-Acadian red clastic unit in the southern Gaspé Peninsula, Quebec. Canadian Journal of Earth Sciences, 39, pp. 1541-1551.
Jutras, P., \& Prichonnet, G. 2004. Integration of geomorphic, sedimentologic and stratigraphic data in the paleogeographic reconstruction of the Paspébiac Graben, a recently identified Late Devonian to Tournaisian basin in the southern Gaspé Peninsula of Quebec, Canada. Geological Society of America Bulletin, 116, in press.

Jutras, P., \& Schroeder, J. 1999. Geomorphology of an exhumed Carboniferous paleosurface in the southern Gaspé Peninsula, Québec; paleoenvironmental and tectonic implications. Géographie Physique et Quaternaire, 53, pp. 249-263.

Jutras, P., Prichonnet, G., \& Von Bitter, P. 1999. The La Coulée Formation, a new post-Acadian stratigraphic unit bearing groundwater calcretes, Gaspé Peninsula, Québec. Atlantic Geology, 35, pp. 139-156.

Jutras, P., Prichonnet, G., \& Utting, J. 2001. Newly identified Carboniferous units (The Pointe Sawyer and Chemindes-Pêcheurs formations) in the Gaspé Peninsula, Quebec; implications regarding the evolution of the northwestern sector of the Maritimes Basin. Canadian Journal of Earth Sciences, 38, pp. 1-19.

Jutras, P., Prichonnet, G., \& McCutcheon, S. 2003. Alleghanian deformation in the eastern Gaspé Peninsula of Quebec, Canada. Geological Society of America Bulletin, 115, pp. 1538-1551.

KePPIE,J.D. 1982. The Minas Geofracture. In Major structural zones and faults of the northern Appalachians. Edited by P. St.-Julien and J. Béland. Geological Association of Canada Special Paper 24, pp. 263-280.

KirKwood, D. 1989. Géologie structurale de la région de Percé. Ministère de l'Énergie et des Ressources, Québec, ET 87-17, 42 p.

Kirkwood, D., Malo, M., St-Julien, P., \& Thérrien, M. 1995. Vertical and fold-axis parallel extension within a slate belt in a transpressive setting, northern Appalachians. Journal of Structural Geology, 17. pp. 329-343.

MALO, M., \& BÉLAND, J. 1989. Acadian strike-slip tectonics in the Gaspé region, Québec Appalachians. Canadian Journal of Earth Sciences, 26, pp. 1764-1777.

Malo, M., \& Kirkwood, D. 1995. Faulting and progressive strain history of the Gaspé Peninsula in post-Taconian time: a review. In Current perspectives in the Appalachian - Caledonian Orogen. Edited by J.P. Hibbard, C.R. van Staal, \& P.A. Cawood. Geological Association of Canada, Special Paper 41, pp. 267-282.

Malo, M., Kirkwood, D., De Broucker, G., \& St.-Julien, P. 1992. A reevaluation of the position of the Baie Verte - Brompton Line in the Québec Appalachians: the influence of Middle Devonian strike-slip faulting in the Gaspé Peninsula. Canadian Journal of Earth Sciences, 29, pp. 1265-1273.

Malo, M., Tremblay, A., Kirkwood, D., \& Cousineau, P. 1995. Along-strike Acadian structural variations in the Québec Appalachians: consuccession of a collision along an irregular margin. Tectonics, 14, pp. 1327-1338.

MAмET, B.L. 1970 Carbonate microfacies of the Windsor 
Group (Carboniferous), Nova Scotia and New Brunswick; Geological Survey of Canada, Paper 70-21, 78p.

Martel, A.T., McGregor, D.C., \& Utting, J. 1993. Stratigraphic significance of Upper Devonian and Lower Carboniferous miospores from the type area of Horton Group, Nova Scotia. Canadian Journal of Earth Sciences, 30, pp. 1091-1098.

McCutcheon, S.R., \& Robinson, P.T. 1987. Geological constraints on the genesis of the Maritimes Basin, Atlantic Canada. In Sedimentary basins and basin-forming mechanisms. Edited by C. Beaumont and A.J. Tankard. Canadian Society of Petroleum Geologists Memoir 12, pp. 287-297.

Murphy, J.B., Rice, R.J., Stokes, T.R., \& Keppie, D.F. 1995. St. Mary's Basin, central mainland Nova Scotia, late Paleozoic basin formation and deformation along the AvalonMeguma Terrane boundary, Canadian Appalachians. In Current perspectives in the Appalachian - Caledonian Orogen. Edited by J.P. Hibbard, C.R. van Staal, \& P.A. Cawood. Geological Association of Canada, Special Paper 41, pp. 409-420.

NANCE, R.D. 1987. Dextral transpression and Late Carboniferous sedimentation in the Fundy coastal zone of southern New Brunswick. In Sedimentary basins and basin-forming mechanisms. Edited by C. Beaumont and A.J. Tankard. Canadian Society of Petroleum Geologists Memoir 12, pp. 363-377.

NANCE, R.D., \& Warner, J.B. 1986. Variscan tectonostratigraphy of the Mispec Group, southern New Brunswick; structural geometry and deformational history. Geological Society of Canada Paper 86-1A, pp. 351-358.

New Brunswick Department Of Natural Resources And Energy 2000. Bedrock Geology of New Brunswick. Minerals and Energy Division. Map NR-1 (2000 Edition), Scale 1:500 000 .

Окицiтch, A.V. 1999. Geological Time Chart 1999. In The National Earth Science Series Geological Atlas. Edited by A.V. Okulitch. Geological Survey of Canada Open-File 3040, Revision from GEOLOG 29, part. I.

Pascucci, V, Gibling, M.R., \& Williamson, M.A. 2000. Late Paleozoic to Cenozoic history of the offshore Sydney Basin, Atlantic Canada. Canadian Journal of Earth Sciences, 37, pp. 1143-1165.

Peulvast J.-P., Bouchard, M., Jolicoeur, S., Pierre, G., \& Schroeder, J. 1996. Paleotopographies and Post-Orogenic Morphotectonic Evolution Around the Baie-des-Chaleurs (Eastern Canada). Geomorphology, 16, pp. 5-32.

Prichonnet, G., Di Vergilio, M., \& ChidiaK, Y. 1996. Stratigraphical, sedimentological and paleontological context of the Escuminac Formation: Paleoenvironmental hypothesis. In Devonian fishes and plants of Miguasha, Quebec,
Canada. Edited by H.-P. Schultze and R. Cloutier. Verlag Dr. Friedrich Pfeil, Munich, pp. 23-36.

Reed, B.C., Nance, R.D., Calder, J.H., \& Murphy, J.B. 1993. The Athol syncline: tectonic evolution of a Westphalien A-B depocenter in the Maritimes Basin, Nova Scotia. Atlantic Geology, 29, pp. 179-186.

Rodgers, J. 1967. Chronology of tectonic movements in the Appalachian region of Eastern North-America. American Journal of Science, 265, pp. 408-427.

Ruitenberg, A.A., \& McCutcheon, S.R. 1982. Acadian and Hercynian structural evolution of southern New Brunswick. In Major structural zones and faults of the northern Appalachians. Edited by P. St.-Julien and J. Béland. Geological Association of Canada Special Paper 24, pp. 131-148.

Ryan, R.J., Boehner, R.C., \& CALDER, J.H. 1991. Lithostratigraphic Revisions of the upper Carboniferous to lower Permian strata in the Cumberland Basin, Nova Scotia and their regional implications for the Maritimes Basin in Atlantic Canada. Bulletin of Canadian Petroleum Geology, 39, pp. 289-314.

St-Julien, P., \& Hubert, C. 1975. Evolution of the Taconian Orogen in the Quebec Appalachians. American Journal of Science, 275-A, pp. 337-362.

UtTing, J. 1987. Palynology of the Lower Carboniferous Windsor Group and Windsor-Canso boundary beds of Nova Scotia, and their equivalents in Québec, New Brunswick and Newfoundland. Geological Survey of Canada Bulletin, 374, 34 p.

Utting, J., Keppie, J.D., \& Giles, P.S. 1989. Palynology and stratigraphy of the Lower Carboniferous Horton Group, Nova Scotia. In Contributions to Canadian Paleontology, Geological Survey of Canada Bulletin, 396, pp. 117-143.

WALKer, J.A., \& McCutcheon, S.R. 1994. Siluro-Devonian tectonostratigraphy of the Tetagouche Lakes map area (NTS 21 O/9), Restigouche County, New Brunswick. In Current Research 1993. Edited by S.A.A. Merlini. New Brunswick Department of Natural Resources, Minerals and Energy Division, Miscellaneous Report 12, pp. 205-214.

Wilcox, R.E., Harding, T.P., \& SeEley, D.R. 1973. Basic wrench tectonics. American Association of Petrology and Geology Bulletin, 57, pp. 74-96.

Yeo, G.M., \& Ruixiang, G. 1987. Stellarton Basin, a pull-apart basin. In Sedimentary basins and basin-forming mechanisms. Edited by C. Beaumont and A.J. Tankard. Canadian Society of Petroleum Geologists Memoir 12, pp. 298-309.

Editorial responsibility: Sandra M. Barr 
